\title{
Pengaruh Pemberian Molases dan Gula Pasir Terhadap pH dan Produksi Silase Rumput Gajah (Pennisetum purpureun sp).
}

\author{
Wakano F. $^{1)^{*}}$, B. Nohong ${ }^{2)}$, Rinduwati ${ }^{2}$, \\ 1) Mahasiswa Program Strata Satu Departemen Nutrisi dan Makanan Ternak, \\ Fakultas Peternakan, Universitas Hasanuddin. \\ 2) Dosen Program Strata Satu Departemen Nutrisi dan Makanan Ternak, Fakultas \\ Peternakan, Universitas Hasanuddin. \\ Email: Fakhruddinwakano03@gmail.com.
}

\begin{abstract}
Abstrak
Pengawetan hijauan dengan metode silase telah banyak dipraktekkan oleh peternak, Salah satu faktor yang mempengaruhi keberhasilan pembuatan silase adalah penambahan zat aditif, seperti molases. Namun, molases tidak tersedia disemua daerah. Untuk itu diperlukan suatu bahan yang dapat menjadi alternatif pengganti silase, yaitu gula pasir, selain memiliki nilai nutrisi yang hampir sama dengan molases, gula pasir juga mengandung water soluble carbohydrate (WSC) yang mudah dimanfaatkan oleh bakteri asam laktat sebagai sumber energi selama proses ensilage. Penelitian ini bertujuan untuk mengetahui pengaruh level molases dan gula pasir terhadap nilai $\mathrm{pH}$ dan bahan kering silase rumput gajah. Penelitian menggunakan rancangan acak lengkap (RAL) dengan 5 perlakuan dan 3 ulangan yaitu P1: kontrol, P2: Molases 4\%, P3: Gula Pasir 4\%, P4: Molases 6\% dan P5: Gula pasir 6\%. Sehingga total unit sampel sebanyak 15 unit serta satu unit sampel bahan segar. Sampel dianalisis di laboratorium untuk mengetahui nilai $\mathrm{pH}$ dan bahan kering dari silase. Hasil penelitian menunjukkan bahwa pemberian aditif gula pasir pada level $4 \%$ pada silase memiliki kualitas yang sama dengan silase yang diberi molases dengan level $4 \%$. Namun, pada taraf $6 \%$ silase yang diberi molases memiliki kualitas yang lebih baik dibanding dengan silase yang diberi gula pasir. Hal ini menunjukkan bahwa gula pasir dapat dijadikan alternatif pengganti molases pada pembuatan silase.
\end{abstract}

Kata Kunci: Rumput Gajah, Silase, Gula Pasir, Molases, pH dan Bahan Kering 


\begin{abstract}
Preservation of forage with silage method has been widely practiced by farmers, one of the factors that influence the success of making silage is the addition of additives, such as molasses. However, molasses is not available in all regions. For that we need a material that can be an alternative substitute for silage, namely granulated sugar, besides having nutritional value that is almost the same as molasses, sugar also contains water soluble carbohydrate (WSC) which is easily utilized by lactic acid bacteria as an energy source during the ensilage process. This study aims to determine the effect of molasses and sugar levels on $\mathrm{pH}$ values and dry matter of elephant grass

silage. The study used a completely randomized design (CRD) with 5 treatments and 3 replications, namely P1: control, P2: Molases 4\%, P3: Sugar 4\%, P4: Molases 6\% and P5: 6\% sugar. So that the total sample unit is 15 units and one unit of fresh material samples. Samples were analyzed in the laboratory to determine the $\mathrm{pH}$ value and dry matter of silage. The results showed that the administration of sugar additives at the level of $4 \%$ in silage had the same quality as silage which was given molasses at the level of 4\%. However, at the level of 6\% silage which is given molasses it has better quality than silage which is given sugar. This shows that granulated sugar can be used as an alternative to molasses in making silage.
\end{abstract}

Keywords: Elephant Grass, Silage, Sugar, Molases, $p H$ and Dri Matter

\title{
PENDAHULUAN
}

Rumput gajah (Pennisetum purpureum sp) adalah tanaman yang dapat tumbuh di daerah marginal. Tanaman ini juga dapat hidup pada tanah kritis dimana tanaman lain relatif tidak dapat tumbuh dengan baik (Sadjadi dkk., 2017). Rumput gajah dipilih sebagai pakan ternak karena memiliki produktifitas yang tinggi dan memiliki sifat memperbaiki kondisi tanah (Rahmawati, 2014). Pada saat musim hujan, produksi hijauan sangat berlimpah namun sebaliknya saat musim kemarau produksi hijauan terbatas. Sehingga diperlukan suatu metode pengawetan untuk memperpanjang masa simpan hijauan tersebut, salah satunya ialah pembuatan silase.

Silase adalah pakan yang diawetkan melalui proses ensilase, yaitu proses pengawetan pakan atau hijauan melalui fermentasi asam laktat dalam kondisi anaerob. Bakteri asam laktat (BAL) memfermentasi karbohidrat terlarut dalam air pada tanaman menjadi asam laktat dan sebagian kecil diubah menjadi asam asetat. Produksi asam dari proses ensilase membuat $\mathrm{pH}$ silase mengalami penurunan dan 
akibatnya aktivitas mikrobia pembusuk dapat dihambat pertumbuhannya (Chen dan Weinberg, 2008).Salah satu faktor yang mempengaruhi keberhasilan silase ialah penambahan zat aditif.

Penambahan zat aditif pada silase bertujuan untuk mendapatkan fermentasi yang berkualitas, mengurangi fermentasi yang tidak diinginkan dan meningkatkan nilai nutrisi silase sehingga dapat meningkatkan performa ternak (Harahap, 2017). Molases umumnya digunakan sebagai zat aditif silase namun, molases tidak tersedia di semua daerah, sehingga perlu mencari suatu bahan yang dapat menjadi alternatif pengganti molases salah satunya ialah gula pasir.

\section{METODE PENELITIAN}

\section{Waktu dan Tempat}

Penelitian ini dilaksanakan pada bulan Desember 2018. Pembuatan silase dilaksanakan di Laboratorium Uji Pakan dan Nutrisi Ternak Ruminansia Fakultas Peternakan Universitas Hasanuddin. Pengukuran parameter dilakukan di Laboratorium Kimia Pakan Fakultas Peternakan Universitas Hasanuddin.

\section{Materi Penelitian}

Alat yang digunakan pada penelitian ini adalah timbangan, parang, wadah, $\mathrm{pH}$ meter, dan seperangkat alat pengukuran bahan kering.

Bahan yang digunakan pada penelitian ini terdiri atas rumput gajah (Pennisetum purpureum sp), molases, gula pasir, lakban, kantong plastik, amplop kertas dan air.

\section{Metode Penelitian}

\section{a. Rancangan percobaan}

Penelitian ini disusun menurut rancangan acak lengkap (RAL) menurut Gazperz, (1991) yang terdiri atas 5 perlakuan dan 3 ulangan, sebagai berikut ; $\mathrm{P}_{1}$ (Rumput gajah tanpa aditif (Kontrol)); $\mathrm{P}_{2}$ (Rumput gajah $+4 \%$ molases); $\mathrm{P}_{3}$ (Rumput gajah $+4 \%$ larutan gula pasir); $\mathrm{P}_{4}$ (Rumput gajah $+6 \%$ molases); dan $\mathrm{P}_{5}$ (Rumput gajah $+6 \%$ larutan gula pasir) 


\section{b. Pelaksanaan penelitian}

Rumput gajah yang berumur \pm 2 bulan dipotong kemudian dilayukan beberapa jam hingga kadar air berkisar antara $65-70 \%$, kemudian rumput dicacah sepanjang $\pm 3 \mathrm{~cm}$ dan ditimbang $2,5 \mathrm{~kg}$ untuk masing-masing kantong. Setelah itu rumput dimasukkan kedalam silo/kantong, untuk yang diberi aditif pemberian aditif dilakukan secara bertahap didalam silo sambil diaduk agar aditif merata. Setelah itu, kantong plastik kemudian di tutup rapat sambil ditekan kuat agar kondisi hampa udara dapat tercapai. Kemudian silase disimpan ditempat yang tidak terkena sinar matahari secara langsung dan difermentasikan selama \pm 21 hari. Setelah \pm 21 hari silase kemudian dibuka untuk dilakukan pengukuran parameter.

Pengukuran parameter dilakuan dengan cara membuka silo kemudian mengukur $\mathrm{pH}$ silase dengan menggunakan $\mathrm{pH}$ meter digital. Selanjutnya, memisahkan silase yang baik dengan silase yang rusak. Setelah itu, mengambil sampel sebanyak $100 \mathrm{~g}$ untuk dilakukan pengukuran bahan kering. Sampel dioven selama \pm 24 jam setelah itu sampel dikeluarkan kemudian melakukan penimbangan.

\section{HASIL DAN PEMBAHASAN}

Rata-rata hasil pengukuran parameter silase rumput gajah yang diberikan molases dan gula pasir dengan level berbeda dapat dilihat pada Tabel 1. Sebagai berikut.

Tabel 1. Rata-rata nilai $\mathrm{pH}$, produksi dan bahan kering silase yang diberi level molases dan gula pasir yang berbeda

\begin{tabular}{|c|c|c|c|c|}
\hline \multirow[b]{2}{*}{ Perlakuan } & \multirow[b]{2}{*}{$\mathrm{pH}$} & \multicolumn{2}{|c|}{ Silase } & \multirow[b]{2}{*}{$\mathrm{BK}(\%)$} \\
\hline & & $\begin{array}{c}\text { Segar } \\
\text { (g/polybag) }\end{array}$ & $\begin{array}{c}\text { Kering } \\
\text { (g/polybag) }\end{array}$ & \\
\hline P1 & $4,67^{\mathrm{c}}$ & $1419,33^{\mathrm{c}}$ & $356,10^{\mathrm{c}}$ & $25,00^{\mathrm{a}}$ \\
\hline $\mathrm{P} 2$ & $3,90^{\mathrm{ab}}$ & $2266,00^{\mathrm{b}}$ & $577,75^{\mathrm{b}}$ & $25,50^{\mathrm{a}}$ \\
\hline P3 & $4,00^{\mathrm{b}}$ & $2348,00^{\mathrm{ab}}$ & $611,00^{\mathrm{ab}}$ & $26,03^{\mathrm{a}}$ \\
\hline P4 & $3,77^{\mathrm{a}}$ & $2380,00^{\mathrm{ab}}$ & $630,86^{\mathrm{ab}}$ & $26,50^{\mathrm{a}}$ \\
\hline P5 & $4,03^{\mathrm{b}}$ & $2407,33^{\mathrm{a}}$ & $650,12^{\mathrm{a}}$ & $27,00^{\mathrm{a}}$ \\
\hline
\end{tabular}

Keterangan : Huruf yang berbeda $(a, b)$ dan $(a, c)$ pada kolom yang sama menunjukkan berbeda nyata $(\mathrm{P}<0,05)$ dan sangat nyata $(\mathrm{P}<0,01)$. 


\section{Nilai pH Silase}

Hasil sidik ragam menunjukkan bahwa pemberian bahan aditif berupa molases dan gula pasir dengan level berbeda memberikan pengaruh yang nyata $(\mathrm{P}<0,05)$ terhadap nilai $\mathrm{pH}$ silase rumput gajah (Tabel 1).

Uji Duncan menunjukkan bahwa nilai $\mathrm{pH}$ silase rumput gajah pada perlakuan $\mathrm{P} 1$ berbeda sangat nyata $(\mathrm{P}<0,01)$ lebih tinggi dibanding dengan perlakuan $\mathrm{P} 2$ dan $\mathrm{P} 4$ dan berbeda nyata $(\mathrm{P}<0,05)$ dengan $\mathrm{P} 3$ dan $\mathrm{P} 5$, sedangkan perlakuan $\mathrm{P} 2$, P3 dan P5 tidak berbeda nyata $(\mathrm{P}>0,05)$. Berdasarkan nilai $\mathrm{pH}$ silase pada Tabel 1, menunjukkan bahwa pemberian aditif molases dan gula pasir 4-6\% menghasilkan silase yang berkualitas baik. Menurut Skerman dan Riveros (1990), standar kualitas silase dari nilai $\mathrm{pH}$ yaitu ; $\mathrm{pH}<4,2$ berkualitas baik, $\mathrm{pH}$ 4,3 - 4,5 berkualitas sedang dan $\mathrm{pH}>4,5$ berkualitas buruk. Penggunaan gula pasir $4 \%$ menghasilkan nilai $\mathrm{pH}$ yang sama dengan penggunaan molases $4 \%$. Jadi, gula pasir dapat digunakan sebagai aditif silase yang sama baiknya dengan silase yang menggunakan aditif molases $4 \%$. Pada taraf $6 \%$ molases menghasilkan silase yang lebih baik ( $\mathrm{pH} 3,77$ ) dibandingkan dengan menggunakan aditif gula pasir ( $\mathrm{pH} 4,03)$.

Penurunan $\mathrm{pH}$ silase terjadi akibat dari aktifitas mikroba selama proses ensilage, bakteri asam laktat (BAL) akan memanfaatkan gula sederhana pada hijauan maupun aditif sebagai sumber energi dan merombak senyawa kompleks menjadi zatzat sederhana, aktifitas tersebut akan menurunkan $\mathrm{pH}$ dari silase. Hal ini sejalan dengam pendapat Wyss dan Rubenshuh (2012) bahwa efek utama dari mikroba (inokulan) adalah meningkatkan produksi asam laktat yang berkaitan dengan penurunan nilai $\mathrm{pH}$ yang signifikan, meningkatkan kualitas silase dan meminimalkan kehilangan bahan kering.

\section{Produksi Silase Segar}

Rata-rata produksi silase segar yang diberi aditif molases dan gula pasir dengan level yang berbeda disajikan pada Tabel 1. Hasil sidik ragam menunjukkan bahwa pemberian bahan aditif berupa molases dan gula pasir dengan level berbeda 
memberikan pengaruh yang nyata $(\mathrm{P}<0,05)$ dan sangat nyata $(\mathrm{P}<0,01)$ terhadap produksi silase segar pada tiap perlakuan.

Hasil uji Duncan menunjukkan bahwa produksi silase segar pada perlakuan $\mathrm{P} 1$ berbeda sangat nyata $(\mathrm{P}<0,01)$ lebih rendah dibanding dengan perlakuan $\mathrm{P} 5$ dan berbeda nyata $(\mathrm{P}<0,05)$ dengan perlakuan $\mathrm{P} 2, \mathrm{P} 3$ dan $\mathrm{P} 4$, sedangkan perlakuan $\mathrm{P} 2$ berbeda nyata $(\mathrm{P}<0,05)$ dengan perlakuan $\mathrm{P} 5$, dan pada perlakuan $\mathrm{P} 2, \mathrm{P} 3$, dan $\mathrm{P} 4$ tidak berbeda nyata $(\mathrm{P}>0,05)$. Berdasarkan produksi silase pada Tabel 1. menunjukkan bahwa pemberian aditif molases dan gula pasir 4 - 6\% menghasilkan silase dengan tingkat kerusakan lebih sedikit dibanding dengan silase tanpa aditif. Rata-rata persentase tingkat kerusakan silase yang diberi aditif lebih rendah $(\mathrm{P} 2$ : 9,36\%; P3 : 6,0\%; P4: 4,80\%; dan P5: 3,70\%) dibanding dengan silase yang difermentasi tanpa aditif (P1: 43\%). Hal ini menunjukkan bahwa silase pada perlakuan P2 sampai P5 berkualitas baik. Menurut Horrocks danVallentine (1999) kerusakan bahan kering selama fermentasi umumnya berkisar antara 5-20\%, dengan rata-rata $10-11 \%$. Kehilangan gas berkisar antara 5-10\% dan kelembaban berkisar antara $72-82 \%$, dan rembesan dibawah $65 \%$ dapat dikategorikan normal

Kerusakan bahan kering umumnya terjadi di permukaan silo yang disebabkan proses pengemasan yang kurang padat sehingga terdapat udara didalam silo yang menyebabkan tumbuhnya jamur dan merusak kualitas dan produksi silase. Menurut Ratnakomala dkk. (2006) kerusakan silase diperhitungkan sebagai persentase dari silase yang rusak dibandingkan dengan jumlah keseluruhan silase dalam satu silo. Silase yang mengalami kerusakan dapat terlihat dari tekstur silase yang rapuh berwarna coklat kehitaman dan berbau busuk serta banyak ditumbuhi jamur. Poin terpenting dalam pembuatan silase yang baik yaitu berat kering dari material antara $35-40 \%$, pengemasan yang kuat dan rapat, temperatur penyimpanan dan adanya bakteri asam laktat homofermentatif. 


\section{Produksi Silase Kering}

Rata-rata produksi silase kering yang diberi aditif molases dan gula pasir dengan level yang berbeda disajikan pada Tabel 1. Hasil sidik ragam menunjukkan bahwa pemberian bahan aditif berupa molases dan gula pasir dengan level berbeda memberikan pengaruh yang nyata $(\mathrm{P}<0,05)$ dan sangat nyata $(\mathrm{P}<0,01)$ terhadap produksi silase kering pada tiap perlakuan.

Hasil uji Duncan menunjukkan bahwa produksi silase kering pada perlakuan P1 berbeda sangat nyata $(\mathrm{P}<0,01)$ lebih rendah dibanding dengan perlakuan $\mathrm{P} 5$ dan berbeda nyata $(\mathrm{P}<0,05)$ dengan perlakuan $\mathrm{P} 2, \mathrm{P} 3$ dan $\mathrm{P} 4$, sedangkan perlakuan $\mathrm{P} 2$ berbeda nyata $(\mathrm{P}<0,05)$ dengan perlakuan $\mathrm{P} 5$, dan pada perlakuan $\mathrm{P} 2, \mathrm{P}$, dan $\mathrm{P} 4$ tidak berbeda nyata $(\mathrm{P}>0,05)$. Pada Tabel 1 . menunjukkan bahwa pemberian aditif molases dan gula pasir 4 - 6\% menghasilkan silase kering yang lebih tinggi dibanding dengan silase tanpa aditif. Hal ini menunjukkan bahwa tingkat kerusakan bahan kering silase yang diberi aditif lebih sedikit. Rata-rata tingkat kerusakan bahan kering masing-masing yaitu P1: 25,75\%; P2: 27,92\%; P3: 30,24\%; P4: 33,97\% dan P5 59,45\%. Menurut Muck dan Kung (2007) bahwa kerusakan menyatakan bahwa kisaran persentase kehilangan bahan kering pada setiap jenis silo dan metode penyimpanan silase yaitu; penyimpanan dengan cara ditumpuk berkisar antara 10$35 \%$, penyimpanan didalam silo $8-30 \%$ dan penyimpanan didalam plastik yang dipadatkan berkisar antara 3-40\%.

\section{Bahan Kering}

Uji Duncan menunjukkan bahwa bahan kering silase pada perlakuan P1, P2, P3, P4 dan P5 tidak menunjukkan perbedaan yang nyata $(\mathrm{P}>0,05)$. Perlakuan $\mathrm{P} 4$ (molases 6\%) dan P5 (gula pasir 6\%) memiliki rataan bahan kering yang lebih tinggi dibandingkan dengan perlakuan P1 (kontrol) yang tidak menggunakan aditif. Penambahan bahan aditif molases dan gula pasir tidak memberikan pengaruh yang nyata terhadap persentase bahan kering, meskipun demikian ada kecenderungan peningkatan persentase bahan kering seiring dengan peningkatan level bahan aditif yang digunakan. Peningkatan bahan kering disebabkan karena aditif yang digunakan 
mengandung bahan kering yang cukup tinggi. Penelitian dari Faturrahman dkk. (2015) didapatkan bahwa terjadi kenaikan kandungan bahan kering seiring dengan penambahan molases pada pembuatan silase dari yang terendah (P0) sampai yang tertinggi (P3). Pada kejadian ini dapat dijelaskan bahwa hal tersebut terjadi karena adanya penambahan molases yang memiliki kandungan bahan kering yang tinggi sehingga meningkatkan kandungan bahan kering silase.

Pada umumnya, proses fermentasi akan menurunkan kandungan bahan kering pada hijauan, hal ini disebabkan karena adanya peristiwa kehilangan bahan kering selama proses ensilage berlangsung. Sehingga, persentase bahan kering dari hijauan asal sebesar 35\% turun menjadi 25-27\%. Hal ini sesuai dengan pendapat Köhler et al. (2013), yang menyatakan bahwa kehilangan bahan kering selama proses ensiling berlangsung pada rumput yaitu 2-25\%, pada jagung 4-19\% dan pada alfalfa $6-15 \%$. Kehilangan bahan kering juga dapat disebabkan oleh pemanasan saat pengovenan sampel. Hal sesuai dengan pendapat Robinson et al. (2016) yang menyatakan bahwa kehilangan bahan kering juga terjadi karena proses penguapan senyawa volatil selama proses pengeringan di dalam oven.

\section{KESIMPULAN}

Berdasar hasil penelitian dan pembahasan dapat disimpulkan bahwa silase yang difermentasikan menggunakan gula pasir pada level $4 \%$ memiliki kualitas yang tidak jauh berbeda dengan silase yang difermentasikan dengan molases pada level yang sama. Hal ini menunjukkan bahwa gula pasir dapat digunakan sebagai bahan aditif alternatif pengganti molases.

\section{DAFTAR PUSTAKA}

Chen, Y. dan Z. G. Weinberg. 2008. Changes during aerobic exposure of wheat silages. Anim. Feed Sci. Technol. 154:76-82.

Faturrahman, F. Atun, B. dan Tidi, D. 2015. Pengaruh tingkat penambahan molases pada pembuatan silase kulit umbi singkong (Mannihot esculenta) terhadap kandungan bahan kering, bahan organik, dan HCN. Fakultas Peternakan, Universitas Padjadjaran. 
Horrocks, R. D. and Vallentine, J. F. 1999. Harvested Forages. Academic Press. New York.

Köhler, B., M. Diepolder, J. Ostertag, S. Thurner, and H. Spiekers. 2013. Dry matter losses of grass, lucerne and maize silages in bun-ker silos. Agric. Food Sci. 22:145-150.

Muck, R.E., and Kung, Jr. L. (2007). Forages : silage production. The Science af Grassland Agriculture. 11(40) : 617-633.

Rahmawati. 2014. Kandungan ADF, NDF selulosa, hemiselulosa dan lignin silase pakan komplit berbahan dasar rumput gajah (Pennisetum pupureum) dan beberapa level biomassa murbei (Morus alba). Skripsi Fakultas Peternakan Universitas Hasanuddin.

Ratnakomala, S., R. Ridwan, G. Kartina dan Y. Widyastuti. 2006. Pengaruh inokulum lactobacillus plantarum 1A-2 dan 1BL-2 terhadap kualitas silase rumput gajah (Pennisetum purpureum). Biodiversitas. 7(2) : 131-134.

Robinson, P. H., N. Swanepoel, J. M. Heguy, and D. M. Meyer. 2016. Total 'shrink' losses and where they occur in commercially sized silage piles constructed from mature and immature cereal crops. Sci. Total Environ. 559:45-52

Sadjadi, B. Herlina, dan W. Supendi. 2017. Level penambahan bokashi kotoran sapi terhadap pertumbuhan dan produksi pada panen pertama rumput raja (Pennisetum purpureophiodes). Jurnal Sains Peternakan Indonesia. 12(4): 411418.

Skerman, P.J. dan F. Riveros. 1990. Tropical Grasses. Food and Agriculture Oerganization. United Nations

Wyss, U. and Rubensuh, U. 2012. Effect of three different silage inoculants on the fermentation quality abd aerobic stability of ryegrass ansiled with three different prewilting degrees. In: kuoppala, K. et al. (eds) Proceedings of the $16^{\text {th }}$ international silage conference, 2-4 july, MTT Agrifood Research Finland. University of Helsinki, Hameenlinna, Finland. P. 386-387. 